\title{
Safety risk assessment based on reloading airdrop mission
}

\author{
Jihui $\mathrm{Xu}^{1, \mathrm{a}}$, Tengfei Liu ${ }^{2, \mathrm{~b}}$, Wenjie Tian*3,c ${ }^{*}$ Xiaolin Wang ${ }^{4, \mathrm{~d}}$, Jing Zhang ${ }^{5, \mathrm{e}}$, Yujin Chen ${ }^{6, \mathrm{f}}$ \\ ${ }^{1}$ Equipment Management and UAV Engineering College, Air Force Engineering University, Xi'an,China \\ ${ }^{2}$ Equipment Management and UAV Engineering College, Air Force Engineering University, Xi'an,China \\ ${ }^{3}$ Equipment Management and UAV Engineering College, Air Force Engineering University, Xi'an,China \\ ${ }^{4}$ Equipment Management and UAV Engineering College, Air Force Engineering University, Xi'an,China \\ ${ }^{5}$ Equipment Management and UAV Engineering College, Air Force Engineering University, Xi'an,China \\ ${ }^{6}$ Equipment Management and UAV Engineering College, Air Force Engineering University, Xi'an,China
}

\begin{abstract}
Implementing risk assessment is of great significance to aviation safety. At present, with the gradual assembly of large transport aircraft with troops, it has become an urgent matter to carry out reloading airdrop to achieve the desired combat purpose and effect. In this paper, the task process of reloading airdrop is described in detail, the risk evaluation index system is established by using the questionnaire, and the probability and severity of the evaluation index are scored, and the risk grade is determined according to the risk matrix. Finally, the fuzzy analytic hierarchy process is used for risk assessment, and the corresponding preventive measures are put forward. The evaluation results show that in the process of heavy load airdrop, attention should be paid to the possibility of aircraft instability during the process of equipment and materials delivery.
\end{abstract}

\section{Introduction}

With the evolution of military forms, the battlefield status of the air force has been increasingly enhanced, especially the development of strategic airlift force, which has created conditions for the rapid maneuvering of the air force. It is regarded as an important measure to improve the battlefield situation and quickly seize the initiative in the battlefield by using large transport aircraft to carry out heavy airdrop. Heavy airdrop refers to the dropping of more than 1 ton of heavy weapons and equipment from the air to a designated area, so as to ensure that airborne troops have long-range mobility and strong firepower assault ability[1]. In recent years, the international safety risk accidents caused by the system safety problems of heavy airdrop are also increasing, and the occurrence of safety risk accidents is not accidental. Therefore, to carry out risk assessment for reloading airdrop mission plays an important role in ensuring the safety of transport aircraft.

In [2], Gui Bingying aimed at the process of cargo moving in the cabin, established the dynamics model of airman-cargo system for heavy loading and airdrop, and designed Lubang controller to stabilize the flight state of the transport aircraft. In [3], Tang Xiaohui et al. divided the soft-landing process of heavy airdrop into two stages to analyze the landing stability of heavy airdrop. In [4], Lin Yiqun et al. analyzed the influence of four factors, such as airdrop speed, aircraft quality, cargo quality and cargo loading position, on the longitudinal dynamic characteristics of the aircraft and obtained the optimal airdrop state. In [5], Liu Ri et al. studied the application of linear control, dynamic inverse control and other advanced control methods in the design of heavily-mounted airdrop controller, and discussed the existing problems in the design of heavily-mounted airdrop controller.

\section{Safety risk identification of heavy airdrop}

The process of reloading airdrop generally goes through six stages: loading equipment materials, taking off and arriving at the designated airspace, exportation, airborne landing, landing and returning course. However, this paper mainly studies the airborne process related to equipment materials, so the risk factors of aircraft returning course after reloading airdrop are not taken into account.

\subsection{Reload the airdrop mission profile}

- Loading equipment and materials

First of all, the heavy equipment materials are fixed on the cargo platform, and the left and right symmetry is maintained, so that the overall center of gravity of the equipment materials is placed in the center of the cargo platform. The air drop system mainly consists of the traction parachute, the main parachute, the detachment device and the buffer system, and then with the help of the airborne crane, the equipment enters the aircraft through the slide rail.

- Take off and arrive in the designated airspace

ae-mail: changan6018@163.com, be-mail: 937323346@qq.com

c*e-mail: twj-safety@foxmail.com, ${ }^{\mathrm{d}}$ e-mail: wangxiaolin_95@163.com

ee-mail: 846278551@qq.com, fe-mail: ivan_safety@foxmail.com 
The pilot flies the aircraft in a position where the equipment can safely unlock, move in a directional direction, disembark, open the parachute, descend, and land.

\section{- Expansion of equipment and materials}

The guiding umbrella pulls out the traction umbrella. Under the action of wind, the traction umbrella pulls out the equipment materials along the guide rail from the cabin, and ensures that the movement of the equipment materials in the cabin will not cause changes in the center of mass and moment of inertia of the aircraft, which will affect the stability of the aircraft.

- Airborne

After the platform is dismounted, the traction lock is opened, the platform is separated from the traction lock, and the main umbrella package is lifted on the shelf. The main umbrella system is straightened by the traction umbrella, the main umbrella out of the main umbrella package, the top of the traction umbrella is fully open, pull the main umbrella, so that the main umbrella to maintain the proper inflatable posture. After the main canopy is inflated to a certain extent, the closing rope is forced to prevent the main canopy from expanding again, making the main canopy appear "bulb" shape, and reducing the purpose of opening dynamic load of the main canopy. After a few seconds, the closing rope is cut off, and the main umbrella is inflated again and fully stretched to ensure the stable descent of the goods[6].

- Take off and arrive in the designated airspace

When the cargo lands, the buffer acts to absorb the energy of the cargo landing and buffer the cargo. At the moment when the cargo lands, because the air resistance acting on the main parachute suddenly reduces, the landing release lock will quickly detach. At this time, the main parachute will be separated from the cargo to prevent the main parachute from dragging the cargo and causing the cargo to roll over.

\subsection{Construction of safety risk assessment index system for heavy airdrop}

Based on the above identification and analysis of the security risks of the reloading airdrop mission, the key risk factors in the process of the reloading airdrop mission were determined through the questionnaire, and the security risk evaluation index system of the reloading airdrop mission was constructed, as shown in Table I.

Table I. Safety risk evaluation index system for reloading airdrop mission

\begin{tabular}{|c|c|c|}
\hline \multirow{4}{*}{$\begin{array}{c}\text { Risk of } \\
\text { reloading } \\
\text { airdrop } \\
\text { mission A }\end{array}$} & $\begin{array}{c}\text { Risk of loading } \\
\text { equipment and } \\
\text { supplies } \mathrm{B}_{1}\end{array}$ & $\begin{array}{c}\text { The equipment and materials } \\
\text { are not tied to the platform in }\end{array}$ \\
\cline { 2 - 3 } & $\begin{array}{c}\text { Take-off to } \\
\text { designated }\end{array}$ & Airborne crane failure $\mathrm{C}_{2}$ \\
\cline { 2 - 3 } & $\begin{array}{c}\text { Equipment } \\
\text { material out of } \\
\text { the hatch risk } \mathrm{B}_{3}\end{array}$ & $\begin{array}{c}\text { The aircraft is not in position } \\
\mathrm{C}_{3}\end{array}$ \\
\cline { 3 - 3 } & $\begin{array}{c}\text { The aircraft becomes } \\
\text { unstable while the }\end{array}$ \\
\hline
\end{tabular}

\begin{tabular}{|c|c|c|}
\hline \multirow{4}{*}{$\begin{array}{c}\text { Airborne } \\
\text { process risk } \mathrm{B}_{4}\end{array}$} & $\begin{array}{c}\text { Rope sail phenomenon } \\
\text { occurs when equipping out }\end{array}$ \\
\cline { 2 - 3 } & \begin{tabular}{c} 
Traction umbrella failure $\mathrm{C}_{7}$ \\
\cline { 3 - 3 }
\end{tabular} & Damaged main canopy $\mathrm{C}_{8}$ \\
\cline { 3 - 3 } & $\begin{array}{c}\text { Equipment } \\
\text { material landing } \\
\text { risk } \mathrm{B}_{5}\end{array}$ & $\begin{array}{c}\text { Landing detached lock not } \\
\text { open, gear roll over } \mathrm{C}_{11}\end{array}$ \\
\cline { 2 - 3 } & Buffer airbag failure $\mathrm{C}_{12}$ \\
\hline
\end{tabular}

\section{Determination of risk level of reloading airdrop evaluation index}

\subsection{Principle of risk matrix}

The core of risk matrix is to determine the severity and possibility of risk consequences. Establishing standards through risk matrix plays an important role in preventing the occurrence of risk accidents and providing the basis for safety design.

The possibility of risk is the probability of risk occurrence. Probability criterion is used to determine and identify the probability of risk occurrence, that is, the probability of risk factors occurring in the process of reloading airdrop, which is described by "1, 2, 3, 4, 5" respectively according to different degrees. The severity of the risk refers to the extent of the damage caused by the risk, including the size, scope and duration of the damage. Severity criterion is the basis for judging and identifying the severity of consequences of risks, which is described by "1, 2, 3, 4" respectively according to different degrees. The risk matrix diagram is shown in Figure 1.

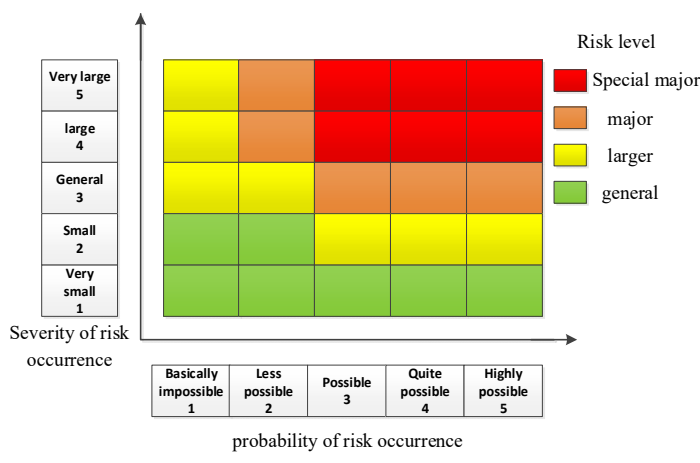

Figure 1 Schematic diagram of risk matrix

\subsection{Risk grade classification}

After determining the safety risk evaluation index system of reinstallation airdrop, the probability and severity of 12 indexes were scored by expert scoring method. The probability level increased successively from 1-5, and the severity level increased successively from 1-4. The risk levels of the occurrence probability and severity of the 12 risk assessment indicators were shown in Table II. 
Table II. Risk grade of risk assessment index

\begin{tabular}{|c|c|}
\hline Risk assessment index & Risk level \\
\hline $\mathrm{C}_{1}$ & larger \\
\hline $\mathrm{C}_{2}$ & larger \\
\hline $\mathrm{C}_{3}$ & larger \\
\hline $\mathrm{C}_{4}$ & larger \\
\hline $\mathrm{C}_{5}$ & major \\
\hline $\mathrm{C}_{6}$ & larger \\
\hline $\mathrm{C}_{7}$ & major \\
\hline $\mathrm{C}_{8}$ & larger \\
\hline $\mathrm{C}_{9}$ & larger \\
\hline $\mathrm{C}_{10}$ & larger \\
\hline $\mathrm{C}_{11}$ & larger \\
\hline $\mathrm{C}_{12}$ & larger \\
\hline
\end{tabular}

\section{Risk assessment of reloading airdrop mission based on fuzzy analytic hierarchy process}

\subsection{Principle of fuzzy analytic hierarchy process}

Fuzzy analytic hierarchy process (FAHP), which combines the advantages of fuzzy method and analytic hierarchy process (AHP), can solve the problem of too many evaluation indexes in a certain hierarchy[7-8]. The fuzzy analytic hierarchy process is to compare the elements according to the importance degree to establish the fuzzy consistent judgment matrix, and calculate the relative weight of each element in the matrix. The fuzzy interpretation matrix can be established through the scale values of the fuzzy analytic hierarchy process determined in Table III.

Table III. Scale values of fuzzy analytic hierarchy process

\begin{tabular}{|c|c|c|}
\hline $\begin{array}{c}\text { Scale } \\
\text { values }\end{array}$ & meaning & specify \\
\hline 0.5 & $\begin{array}{c}\text { As } \\
\text { important }\end{array}$ & The two factors are equally important \\
\hline 0.6 & $\begin{array}{c}\text { A little } \\
\text { important }\end{array}$ & $\begin{array}{c}\text { The former factor is slightly more } \\
\text { important than the latter }\end{array}$ \\
\hline 0.7 & $\begin{array}{c}\text { Obviously } \\
\text { important }\end{array}$ & $\begin{array}{c}\text { The former factor is significantly more } \\
\text { important than the latter }\end{array}$ \\
\hline 0.8 & $\begin{array}{c}\text { It's much } \\
\text { more }\end{array}$ & $\begin{array}{c}\text { The former factor is far more important } \\
\text { than the latter }\end{array}$ \\
\hline 0.9 & $\begin{array}{c}\text { Extremely } \\
\text { important }\end{array}$ & The former factor is more important than \\
the latter
\end{tabular}

The risk fuzzy judgment matrix is established according to the scale value, and the scale value of the fuzzy analytic hierarchy process is defined as follows:

$$
\begin{aligned}
& a_{i j}=0.5, i=j \\
& a_{j i}=1-a_{i j}, i \neq j
\end{aligned}
$$

The specific fuzzy judgment matrix is shown in (2)

$$
A=\left[\begin{array}{ccccc}
0.5 & a_{12} & a_{13} & \cdots & a_{1 n} \\
a_{21} & 0.5 & a_{23} & \cdots & a_{2 n} \\
a_{31} & a_{32} & 0.5 & \cdots & a_{3 n} \\
\vdots & \vdots & \vdots & \ddots & \vdots \\
a_{n 1} & a_{n 2} & a_{n 3} & \cdots & 0.5
\end{array}\right]
$$

The sum of the rows of the fuzzy judgment matrix A. Through mathematical transformation:

$$
r_{i}=\sum_{k=1}^{n} a_{i k}(i=1,2, \ldots, n)
$$

By mathematical variation:

$$
r_{i j}=\frac{r_{i}-r_{j}}{2(n-1)}+0.5
$$

the fuzzy consistent matrix is obtained:

$$
R=\left(r_{i j}\right)_{n \times n}
$$

The row and normalization processing of the matrix $\mathrm{R}$ are carried out to obtain the factor ordering vector:

$$
w=\left(w_{1}, w_{2}, \ldots, w_{n}\right)^{T}
$$

We can obtain:

$$
w_{i}=\frac{2 \sum_{j=1}^{n} r_{i j}-0.5}{n(n-1)}(i=1,2, \ldots, n)
$$

The weight values of each level are converted into the comprehensive weight relative to the task.

\subsection{Risk assessment of reloading airdrop}

By table IV risk factors in different stages of the hierarchy can see important degree of the risk of each risk factor, and every stage of the risk factors are connected in series, so the risk of risk factors in every stage, the greater the number, the more the greater the risk of this phase, is more important, which can determine the stages of scale values as shown in table at each stage.

Table IV. Risk grade division of each stage

\begin{tabular}{|c|c|}
\hline Recharge airdrop at all stages & Risk level \\
\hline Loading equipment supplies & larger \\
\hline Take-off to designated airspace & general \\
\hline Equipment material out of the hatch & major \\
\hline airborne & Special major \\
\hline Landing of equipment supplies & larger \\
\hline
\end{tabular}

According to their importance, fuzzy matrices of A, B1, B2, B3, B4 and B5 were established. After the weight matrix was obtained, the importance of all risk factors in layer $\mathrm{C}$ was compared with that of the top layer $\mathrm{A}$, which was shown in Table V. 
Table V. Weighted values of all risk factors relative to A

\begin{tabular}{|c|c|c|c|c|c|c|}
\hline \multirow{3}{*}{$\begin{array}{c}\text { Specific } \\
\text { risk } \\
\text { factor } \\
\text { C }\end{array}$} & \multicolumn{5}{|c|}{ Each factor and weight } & \multirow{3}{*}{$\begin{array}{c}\text { The } \\
\text { weights } \\
\text { of all } \\
\text { the } \\
\text { factors } \\
\text { with } \\
\text { respect } \\
\text { to } A\end{array}$} \\
\hline & $\mathbf{B}_{1}$ & $\mathbf{B}_{2}$ & $\mathbf{B}_{3}$ & $\mathbf{B}_{4}$ & $\mathbf{B}_{5}$ & \\
\hline & 0.1833 & 0.1415 & 0.2251 & 0.2669 & 0.1833 & \\
\hline $\mathrm{C}_{1}$ & 0.5 & 0 & 0 & 0 & 0 & 0.09165 \\
\hline $\mathrm{C}_{2}$ & 0.5 & 0 & 0 & 0 & 0 & 0.09165 \\
\hline $\mathrm{C}_{3}$ & 0 & 1 & 0 & 0 & 0 & 0.14150 \\
\hline $\mathrm{C}_{4}$ & 0 & 0 & 0.3109 & 0 & 0 & 0.06998 \\
\hline $\mathrm{C}_{5}$ & 0 & 0 & 0.3782 & 0 & 0 & 0.10094 \\
\hline $\mathrm{C}_{6}$ & 0 & 0 & 0.3109 & 0 & 0 & 0.06998 \\
\hline $\mathrm{C}_{7}$ & 0 & 0 & 0 & 0.2878 & 0 & 0.07681 \\
\hline $\mathrm{C}_{8}$ & 0 & 0 & 0 & 0.2374 & 0 & 0.06336 \\
\hline $\mathrm{C}_{9}$ & 0 & 0 & 0 & 0.2374 & 0 & 0.06336 \\
\hline $\mathrm{C}_{10}$ & 0 & 0 & 0 & 0.2374 & 0 & 0.06336 \\
\hline $\mathrm{C}_{11}$ & 0 & 0 & 0 & 0 & 0.5 & 0.09165 \\
\hline $\mathrm{C}_{12}$ & 0 & 0 & 0 & 0 & 0.5 & 0.09165 \\
\hline
\end{tabular}

\subsection{Preventive measures for evaluation indexes of reloading airdrop}

According to the above determination of the importance of each index in the airdrop process of heavy loading, it can be concluded that the risks and accidents are relatively high in the stage of equipment material exit, equipment material landing and equipment material loading, so preventive measures should be taken and sorted out as shown in Table VI.

Table VI. Preventive measures

\begin{tabular}{|c|c|}
\hline Specific risk factors & preventive measure \\
\hline $\begin{array}{c}\text { The equipment and } \\
\text { materials are not tied to } \\
\text { the platform in place } \mathrm{C}_{1}\end{array}$ & $\begin{array}{c}\text { Improve relevant binding and } \\
\text { retention standards. }\end{array}$ \\
\cline { 2 - 2 } & $\begin{array}{c}\text { Increase the training of aircraft } \\
\text { personnel, in accordance with the } \\
\text { relevant standards. }\end{array}$ \\
\hline $\begin{array}{c}\text { Airborne crane failure } \\
\mathrm{C}_{2}\end{array}$ & $\begin{array}{c}\text { Carefully check the quality of the } \\
\text { airborne crane before flight. }\end{array}$ \\
\hline \multirow{2}{*}{$\begin{array}{c}\text { The aircraft is not in } \\
\text { position } \mathrm{C}_{3}\end{array}$} & $\begin{array}{c}\text { Improve the regulations and standards } \\
\text { that different goods should take } \\
\text { different attitudes. }\end{array}$ \\
\cline { 2 - 2 } $\begin{array}{c}\text { Equipment gets stuck in } \\
\text { the guide rail } \mathrm{C}_{4}\end{array}$ & $\begin{array}{c}\text { Intensify the training of pilots. } \\
\text { there are stuck in the guide rail, and } \\
\text { regularly check the quality of the } \\
\text { guide rail. }\end{array}$ \\
\cline { 2 - 2 } & $\begin{array}{c}\text { When designing guide rail, pay } \\
\text { attention to the quality requirements } \\
\text { of guide rail. }\end{array}$ \\
\hline \multirow{2}{*}{$\begin{array}{c}\text { The aircraft becomes } \\
\text { unstable while the } \\
\text { equipment is moving } \mathrm{C}_{5}\end{array}$} & $\begin{array}{c}\text { Before the flight to investigate the } \\
\text { environment at that time, establish a } \\
\text { model, simulate the situation of the } \\
\text { flight, the pilot to prepare. }\end{array}$ \\
\hline & $\begin{array}{c}\text { Conduct field survey before flight, } \\
\text { and pay attention to changes in }\end{array}$ \\
\hline
\end{tabular}

\begin{tabular}{|c|c|}
\hline \multirow{2}{*}{$\begin{array}{l}\text { Rope sail phenomenon } \\
\text { occurs when equipping } \\
\text { out of the cabin } \mathrm{C}_{6}\end{array}$} & $\begin{array}{c}\text { environmental conditions during the } \\
\text { air drop. }\end{array}$ \\
\hline & $\begin{array}{l}\text { Enhance pilot and crew training in } \\
\text { handling special situations. }\end{array}$ \\
\hline $\begin{array}{l}\text { Traction umbrella } \\
\text { failure } \mathrm{C}_{7} \\
\end{array}$ & \multirow{4}{*}{$\begin{array}{l}\text { Check the quality of relevant } \\
\text { components before flight. } \\
\text { The assembly shall be done in } \\
\text { accordance with relevant standards. }\end{array}$} \\
\hline $\begin{array}{l}\text { Damaged main canopy } \\
\qquad \mathrm{C}_{8}\end{array}$ & \\
\hline Closure line failed $\mathrm{C}_{9}$ & \\
\hline Cutter malfunction $\mathrm{C}_{10}$ & \\
\hline \multirow{2}{*}{$\begin{array}{l}\text { Landing detached lock } \\
\text { not open, gear roll over } \\
\qquad \mathrm{C}_{11}\end{array}$} & $\begin{array}{l}\text { The assembly should be done strictly } \\
\text { in accordance with the procedure of } \\
\text { landing release lock. }\end{array}$ \\
\hline & $\begin{array}{l}\text { Check the quality of landing release } \\
\text { locks before flight. }\end{array}$ \\
\hline \multirow[t]{2}{*}{ Buffer airbag failure $C_{12}$} & $\begin{array}{l}\text { In the design of the airbag, the } \\
\text { cushion model and the contact } \\
\text { collision model of the airbag are } \\
\text { established to design the strength, } \\
\text { stiffness and ductility of the airbag. }\end{array}$ \\
\hline & $\begin{array}{c}\text { Check the quality of the buffer airbag } \\
\text { before flight. }\end{array}$ \\
\hline
\end{tabular}

The process of reloading airdrop generally goes through six stages: loading equipment materials, taking off and arriving at the designated airspace, exportation, airborne landing, landing and returning course. However, this paper mainly studies the airborne process related to equipment materials, so the risk factors of aircraft returning course after reloading airdrop are not taken into account.

\section{5 conclusion}

Risk assessment is the basis of preventing aviation safety risk accidents. This paper takes the reloading airdrop mission as the research object, establishes the risk evaluation index system, combines the risk matrix and the fuzzy analytic hierarchy process to carry out the safety risk assessment for the reloading airdrop mission, and obtains the good evaluation effect, and puts forward the corresponding improvement measures. The purpose of this paper is to find out the relatively important risk factors in the task, to provide reference for the troops to carry out the heavy airdrop, and to ensure the corresponding task security.

\section{References}

1. GJB7789-2012, Requirements for Heavy Load Airdrop Test [S].2012

2. Gui Bingying. Research on Dynamic Modeling and Control Technology of Heavy Loading Airdrop [D]. Nanjing University of Aeronautics and Astronautics, 2012.

3. TANG Xiaohui, QIAN Linfang, TANG Jianhua, et al. Analysis of Cushioning Stability for Heavy Vehicle Airdrop Landing [J]. Journal of Vibration and Shock, 2015, 000(015):122-126.

4. Lin Yiqun, Zhang Haini, Fang Zili. Simulation and Analysis of Airdrop System for Heavy Load of 
Transport Aircraft [J]. Aircraft Design, 2015, 035(002):67-71.

5. Liu Ri, Liu Yongbo, Xu Ming, et al. Overview on Several Problems of Airdrop Model and Control for Heavy Loading Transport Aircraft [J]. Electronic Optics \& Control, 2018, 25(11):66-70+76.

6. WU Lei. Dynamics Research of Heavy Equipment Airdrop [D]. Nanjing: Nanjing University of Science and Technology, 2013.

7. Zang Taotao. Research on Optimization of Military Transportation Path Based on Fuzzy Analytic Hierarchy Process (FAHP) [D].Changchun: Jilin University, 2013.

8. Manekar P, Nandy T, Sargaonkar A, et al. FAHP ranking and selection of pretreatment module for membrane separation processes in textile cluster[J]. Bioresource Technology, 2011, 102(2):558-566. 